\title{
本態性血小板血症と出血症状
}

岡田昌也*，徳川多津子，澤田暁宏，日笠 聡

\section{Bleeding complication with essential thrombocythemia}

Masaya OKADA, Tazuko TOKUGAWA, Sawada AKIHIRO, Satoshi HIGASA

要約 : 本態性血小板血症（essential thrombocythemia: ET）は此較的予後良好な骨髄増殖性腫瘍である. 日常診療 では主に血栓症や骨髄線維症, 白血病化などの病勢進行を念頭に置き管理されているが, しばしば血小板数が 高值の状態で出血症状を呈する症例を経験する．この出血症状の原因として後天性 von Willebrand 症候群 (acquired von willebrand syndrome: AvWS) があり, 無症候性を含めると AvWS 合併症例の頻度は高く, ET 患者 の $20 \sim 50 \%$ にられると報告されている. 血小板数コントロールに加え, 軽症例ではトラネキサム酸の使用, 大量出血を併発した際には, von Willebrand 因子（VWF）含有血液凝固第VIII 因子製剤の使用が必要となる. また，ET患者に対し血栓症予防として安易に抗血小板療法開始すると出血リスク悪化の誘因となる．この原因 も AvWS であり，国内外のガイドラインでは，抗血小板療法開始前にVWF 活性 (VWF ristocetin cofactor activity: VWF:RCo）を確認し AvWS 合併の有無を検討する必要があるとされている. 出血傾向は血小板数増多と相反 する症候であるが ET 管理には重要である。本稿では ET における出血症状について, 特に AvWS に関して概 説する.

Key words: essential thrombocythemia, acquired von willebrand syndrome, VWF ristocetin cofactor activity (VWF:RCo)

\section{1. 本態性血小板血症における出血性イベント}

本態性血小板血症 (essential thrombocythemia: ET) 患者の生存率は他の骨髄増殖性腫瘍患者に比し良好 である。しかしながら ET 患者の生命予後はコント ロールと比較し, 発症約 5 年後より不良となる ${ }^{1)}$. ET 患者 867 例を対象とした Pssamonti らの疫学研究 では死亡原因として血栓症 $(51 \%)$, がん $(22 \%)$, 白血病（17\%）についで出血が約 10\%であったと報 告されており ${ }^{2)}$ ，ETにおける出血イベントの管理は 重要である．また，ET患者における出血イベントの 発生頻度はDan らによる本邦での ET 患者 381 例の 疫学研究において $4.2 \%$ であったと報告されてい

\footnotetext{
*責任者連絡先 :

兵庫医科大学病院血液内科

干 663-8501 兵庫県西宮市武庫川町 1-1

Tel: 0798-45-6886, Fax: 0798-45-6887

E-mail: masaya@hyo-med.ac.jp
}

る ${ }^{3)}$ 。一方，イタリアからの疫学研究でも $4 \%$ の患 者に出血の合併が認められており ${ }^{4)}$, ET 患者のおけ る出血イベントは比較的頻繁に起こる合併症である. また, Cambellらは, 高リスク ET 患者に対しハイド ロキシウレア+アスピリンとアナグレリド+アスピリ ンの有効性を検討した非盲検比較臨床試験である PT-1 試験に参加した患者を対象として, 血栓・出血 イベントとその発症前から 60 日以内の血小板数との 関連を検討した。この研究では, 血栓症発症リスク は血小板数増多に伴い増大するが, 出血イベントの 発症リスクと血小板数はU 字型曲線の関係にあり, 出血は過度な治療などによる血小板数減少時だけで なく, 増加時にも発症リスクが増大することが報告 されている5（図1)。

\section{ET における後天性 von Willebrand 症候群}

血小板数が正常〜高值の状態でなぜ出血イベント 


\section{(A) 血栓}

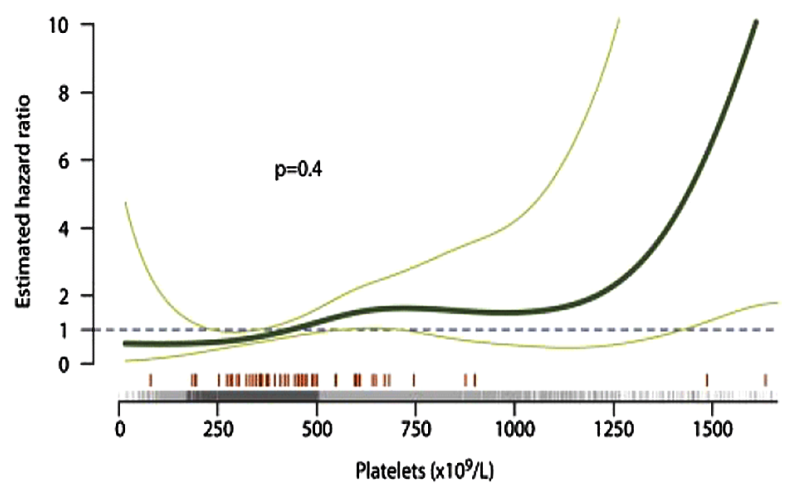

(B) 出血

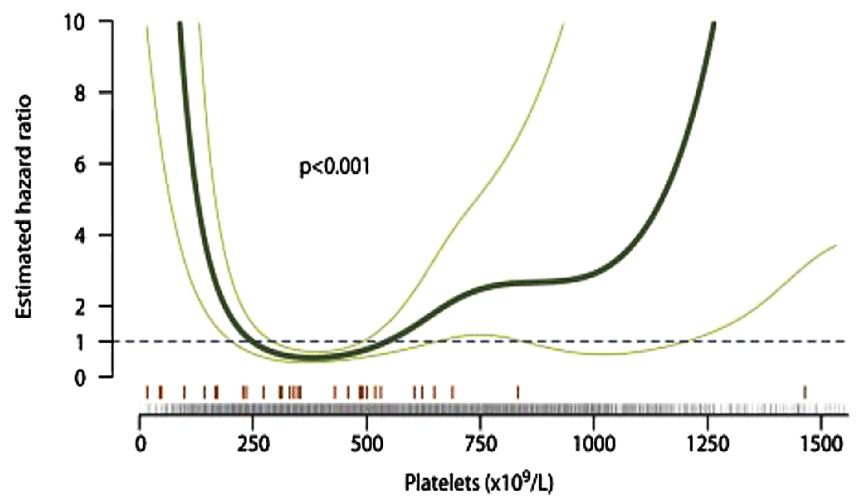

圀 1 血管イベント発症リスクと 60 日以内の血小板数の関係

A）血栓リスクは血小板数 $>125$ 万/ $\mu \mathrm{L}$ 程度から増加, B）出血リスクは血小板減少時と増加時の 2 峰性に有意差をもって 上昇（文献 5 より作成）

が発生するのか? この状態の ET 患者における出血 イベントの原因は血小板機能低下や血管内皮の障害 など複数の要因があげられるが，最もリスクが高い のは後天性 von Willebrand 症候群（acquired von Willebrand syndrome: AvWS）であると考えられてい る. AvWS は様々な原因により，後天的にVWF 活性 (VWF ristocetin cofactor activity: VWF:RCo) が低下し 出血症状をきたす症候群であり，その原因の一部は 甲状腺機能低下などによるVWF 産生低下であるが, 大部分の AvWS はVWF 産生が充進しており (1)自己 免疫疾患などに伴う自己抗体による活性阻害(2)悪性 腫瘍などの細胞への吸着(3)高ずり応力を生じる血管 障害などによる高分子マルチマーの（HMV-VWFM） 分解㐫進などが主な原因となる. ET 患者では増加し た血小板へのVWF の結合や血小板から放出される ADAM10 P ADAM17 によるHMV-VWFM 分解など が原因と考えられている。このため, ETに合併する AvWS の病型は HMV-VWFM が選択的に低下する VWS タイプ 2A 型を呈する.

診断には出血性疾患スクリーニング検査施行時に 血小板数や PT, フィブリノーゲンが正常でAPTTの みが低下している場合，VWSを疑うがAvWSでは FVIII 活性低下が軽度なため APTTが延長しない例が 少なくないことに注意しなければならない.AvWS の診断は通常, VWF:RCo 30\%未満, VWF:RCo/VWF 抗原量（VWF:Ag）が 0.7 以下となることをもってな
されている. また, 補助診断としてVWF マルチマー 解析で HMV-VWFM が減少, 消失していることが, 病型診断に有用であるが現在本邦では保険収載され ていない. なお, 血液型 $\mathrm{O}$ 型者は他血型者と比較し VWF 量が約 $25 \%$ 低值であるため, AvWS の診断, 管 理時に注意する必要がある ${ }^{6)}$.

ET 患者における AvWS 合併頻度について, Mital らは ET 患者 170 例を対象としたポーランドの疫学 研究において $20 \%$ の頻度で合併が認められ, 比較的 若年, へモグロビン高值, 血小板数高值であること がリスク因子と報告している7). 一方, Rottenstreich らの報告ではイスラエルにおいて ET 患者 116 人, 真 性多血症患者 57 人を対象として検討され, ET 患者 の 55\%にAvWS 合併が認められ, AvWS 合併リスク 因子は血小板数高值, 若年者, JAK2V167 変異陽性 者であると報告している. 彼らは, AvWS 合併 ET 患 者の $69.5 \%$ が血小板数 100 万 $/ \mu \mathrm{L}$ 未満であり血小板 数が比較的低值でも AvWS に留意が必要であること を警告している。この報告では AvWS 合併率が極め て高いが，その診断基準が 1. VWF:RCoが血液型 O 型, 非 O 型でそれぞれ $41 \%, 58 \%$ 未満, 2. VWF:RCo/ VWF:Ag 比が 0.7 未満 3. VWD家族歴がない, こ の 1，2，3すべてを認めることとしており，診断基 準の VWF:RCo 閾值が高いことに注意を必要する ${ }^{8)}$. 


\section{3. 低用量アスピリン使用における留意点}

ET 患者管理には血栓予防が優先される. 血栓予防 には低用量アスピリンが使用されるが，AvWS 合併 時に出血のリスクを増長させるため安易な開始には 注意を要する. 日本血液学会造血器腫瘍診療ガイド ライン 2018 年版補訂版では, 60 歳以上もしくは血 栓症の既往を有する高リスク ET 患者は，血栓症の 予防を目的として低用量アスピリン投与と細胞減少 療法の併用療法を行うことが推奨されているが, “血 小板数の著増に伴い von Willebrand 因子（vWF）が 低下すると，AvWS を発症することがある。アスピ リンの単独投与は出血を助長する可能性があるため, vWF:RCo が低下している例では, 細胞減少療法後に 血小板数が減少していることを確認してからアスピ リン投与を行う。血小板数 $<100$ 万 $/ \mu \mathrm{L} て ゙ も \mathrm{vWF}$ 低下する例もみられるため, 出血傾向を示す場合は 血小板数に関わらずvWF:RCo を測定することが望 ましい.”と記載されている ${ }^{9)}$. また, NCCNガイド ラインでは, すべてのリスクの ET 患者に対して治 療開始にあたり AvWS 合併のスクリーニングが必要 と記載されている ${ }^{10)}$.

Larrán らは, 細胞減少療法を行っていない低リス ク ET 患者 433 症例を対象としてアスピリンの有用 性を検討した後方視的研究において, 遺伝子変異の 種類により抗血小板療法の有用性とそのリスクに差 異があることを報告している。 JAK2V167変異陽性 例では，アスピリン内服により血栓予防効果が無治 療経過観察群に比し有意に低下し, 出血発症頻度に は差がなかったが, CALR変異陽性群では血栓予防 に有意差がなく, 出血の発症率が優位に高くなる傾 向が認められた.この研究では AvWS の検討は行わ れておらず, CALR 変異陽性 ET 患者はその血小板機 能が低いことが出血イベント増多の原因ではないか, と考察している，アスピリン投与が主治医判断であ り, CALR 遺伝子変異陽性者の血小板数が高いこと に留意が必要であるが, ET 患者の出血傾向について AvWS だけでなく遺伝子変異の種類により治療方針 を考慮する必要性を示唆する結果であった ${ }^{11)}$.

\section{AvWS の治療}

AvWS の治療は原則, 原病の治療が優先される。 ET においても血小板数が低下すれば VWF:RCo/ VWF:Ag 比が改善することは多くの症例報告で示さ れており ${ }^{12)}$ ，日常臨床でもしばしば経験する。ま た，血小板数のコントロールが良好であれば vWF:RCo 值が正常を下回っていても抗血小板療法を 避けるのみでよい. 止血治療は活動性出血をきたし た際に行われている. 先天性 vWS と同様, 軽度の出 血傾向ではトラネキサム酸内服などによりコント ロール可能であるが, 大量出血などをきたした場合, 血小板数高值例では血小板アフェレーシスにて血小 板数の速やかなコントロールが行ないつつ, 新鮮凍 結血漿, VWF 含有血液凝固第 VIII 因子製剤が使用 されている ${ }^{13)}$. 先天性 vWS で使用されているデス モプレッシンの有用性は限定的である。骨髄増殖性 腫瘍に伴う AvWSには他疾患が原因となったAvWS に比し有用性が低く, 約 $20 \%$ との報告がある ${ }^{14)}$.

\section{5. おわりに}

ET は比較的予後良好な骨髄増殖性腫瘍である. 日 常臨床では血小板数コントロールと血栓症予防のみ が行われることが多いが，しばしば出血症状や止血 困難をきたすことがある．そのリスクとして，年齢， $\mathrm{Hb}$ および血小板数, 遺伝子変異などが示唆されてい るが, まずはVWF:RCo, VWF:Ag などを測定し, 出 血傾向もあわせ診療することが必要である。

著者全員の利益相反（COI）の開示：

本論文発表内容に関連して開示すべき企業等との利 益相反なし

\section{文献}

1) Tefferi A, Guglielmelli P, Larson DR, et al.: Long-term survival and blast transformation in molecularly annotated essential thrombocythemia, polycythemia vera, and myelofibrosis. Blood 124: 2507-2513, 2014.

2) Passamonti F, Thiele J, Girodon F, et al.: A prognostic model to predict survival in 867 World Health Organization-defined essential thrombocythemia at diagnosis: A study by the International Working Group on Myelofibrosis Research and Treatment. Blood 120: 1197-1201, 2012. 
3) Dan K, Yamada T, Kimura Y, et al.: Clinical features of polycythemia vera and essential thrombocythemia in Japan: Retrospective analysis of a nationwide survey by the Japanese Elderly Leukemia and Lymphoma Study Group. Int J Hematol 83: 443-449, 2006.

4) Cortelazzo S, Viero P, Finazzi G, et al.: Incidence and risk factors for thrombotic complications in a historical cohort of 100 patients with essential thrombocythemia. J Clin Oncol 8: 556-562, 1990.

5) Campbell PJ, MacLean C, Beer PA, et al.: Correlation of blood counts with vascular complications in essential thrombocythemia: Analysis of the prospective PT1 cohort. Blood 16: 1409-1411, 1992.

6) 日笠聡：後天性 von Willebrand 症候群の診断と治療. 血. 栓止血誌 29: 699-702, 2018.

7) Mital A, Prejzner W, Bieniaszewska M, et al.: Prevalence of acquired von Willebrand syndrome during essential thrombocythemia: A retrospective analysis of 170 consecutive patients. Pol Arch Med Wewn 125: 914-920, 2015.

8) Rottenstreich A, Kleinstern G, Krichevsky S, et al.: Factors related to the development of acquired vonWillebrand syndrome in patients with essential thrombocythemia and polycythemia vera. Eur J Intern Med 41: 49-54, 2017.

9) 日本血液学会血造血器腫瘍診療ガイドライン 2018 年版 補訂版 http://www.jshem.or.jp/gui-hemali/1_4.html\#soron

10) NCCN Guidelines Myeloproliferative Neoplasms Version 1.2020 https://www.ncen.org/professionals/physician_gls/pdf/ mpn blocks.pdf

11) Alvarez-Larrán A, Pereira A, Guglielmelli P, et al.: Antiplatelet therapy versus observation in low-risk essential thrombocythemia with a CALR mutation. Haematologica 101: 926-931, 2016.

12) Schneider C, Stutz-Grunder E, Lüer S, et al.: Fulminant essential thrombocythemia associated with acquired von Willebrand syndrome and bleeding episodes in a 14-year-old girl. Hamostaseologie 39: 404-408, 2019.

13) Ueki T, Takeshige K, Sumi M, et al.: Successful management of intraperitoneal bleeding with platelet apheresis and von Willebrand factor supplementation in a patient with essential thrombocythemia and acquired von Willebrand syndrome. Rinsho Ketsueki 58: 922-926, 2017.

14) Federici $\mathrm{AB}$, Rand $\mathrm{JH}$, Bucciarelli $\mathrm{P}$, et al.: Acquired von Willebrand syndrome: Data from an international registry. Thromb Haemost 84: 345-349, 2000. 